\title{
RESTRAINT OF TRADE DURING AND ON THE TERMINATION OF A CONTRACT OF EMPLOYMENT
}

\section{I.G.C. Stratton *}

\section{INTRODUCTION AND DEFINITION}

Once the parties have reached an agreement the principle purpose of contract law is to enforce such an agreement and impose penalties on any party in the event of their breach of the contract. This concept applies to contracts of employment ${ }^{1}$ with the exception that where a covenant has been imposed on an employee by an employer restricting the activities of the former during the course of his employment or on the termination of his contract of employment the doctrine of restraint of trade will prima facie render such covenant void on the grounds that it is contrary to public policy and it will only be enforceable if it is reasonable. ${ }^{2}$

The doctrine is therefore, anomalous in the sense that it impinges on the common law principle of freedom of contract, although conversely, the ultimate object of the restraint of trade doctrine is to allow the party subject to the covenant to enter into contracts with third parties despite contractual restrictions against such a course of action, i.e. to allow freedom of trade. Yet in another

\section{" Solicitor.}

${ }^{1}$ Esso Petroleum Ltd. v. Harpers Garage (Stourport) Ltd. [1968] A.C. 269 (H.L.). It should be also be noted contracts of employment can take several forms ranging from lengthy sophisticated service agreements for directors and senior managers to an exchange of letters for junior employees.

${ }^{2}$ Nordenfelt $v$. Moxim Nordenfelt Guns and Ammunition [1894] A.C. 535 at 565 per Lord Macnaghten: "reasonable that is, in reference to the interests of the parties concerned and reasonable in reference to the interests of the public, so framed and so. guarded as to afford adequate protection to the party in whose favour [they are] imposed, while at the same time... in no way injurious to the public." 


\section{DENNING LAW JOURNAL}

sense all contracts restrain trade to some degree by preventing the parties to an agreement from dealing with other parties in relation to the subject matter of a transaction once it has been entered into.

These apparent conceptual dichotomies have given rise to difficulties in defining covenants in restraint of trade. In Esso Petroleum Co. Ltd. v. Harpers Garage (Stourport) Ltd., Lord Reid stated that he "would not attempt to define the dividing line between contracts which are and contracts which are not in restraint of trade." ${ }^{3}$ Nevertheless, judicial attempts have been made to define the doctrine and in particular, by Lord Justice Diplock in Petrofina (Great Britain) Ltd. v. Martin:
"A contract in restraint of trade is one in which a party (the covenantor) agrees with the other party (the covenantee) to restrict his liberty in the future to carry on trade with other persons not parties to the contract in such manner as he chooses." 4

In the context of an employer and employee this definition envisages a negative covenant preventing the employee from working for a third party rather than a positive obligation to work only for the one employer. ${ }^{5}$ Restraint covenants can therefore, restrict an employee from competing directly with business of the employer, but can also operate to protect confidential information, or restrict an employee's personal activities so far as they impinge on the effective running of the employer's business or the requirements of a third party. Apart however from the theoretical aspects of the doctrine of restraint of trade, its application in practice has important implications for an employer and employee. These concerns and the evolution of the doctrine are evidenced by the weight of recent case law on the topic.

\section{THE CONCEPT OF INTEREST}

${ }^{3}$ Supra.n. 1 at 298.

${ }^{4}$ [1966] Ch. 146 at 180. The definition was accepted by Lord Hodson in Esso Petroleum Co. Ltd. v. Harpers Garage (Stourport) Lid. supra.n1 at 317.

${ }^{5}$ See Whitwood Chemicals Co. v. Hardman [1891] 2 Ch. 416 where the court refused an injunction on the grounds that there was no negative covenant. See also Paul Goulding "Injunctions and Contracts of Employment: the Evening Standard Doctrine" (1990) 19 I.L.J. 98. 


\section{RESTRAINT OF TRADE}

The concept of interest, when applied to restraint covenants, falls under two main headings, which apply not only to employment contracts, but also other contractual circumstances such as a restraint covenant imposed on the vendor of a business; a retiring partner; or a former shareholder under a joint venture agreement. Accordingly such covenants must be reasonable in the interests of both the public and the parties concerned. ${ }^{6}$

The reasons for restraint covenants on the first ground of public interest, both during and after employment, arise as they are anti-competitive; restrict the mobility of labour; and militate against full employment all, of which are fully justifiable from both an economic and social point of view. ${ }^{7}$ However, that is not to say that such covenants are not without their jurisprudential problems. The courts have tended to treat the concept of public interest with circumspection because of its wide and general nature which can create uncertainty. ${ }^{8}$ One cause for such uncertainty is that the courts have little or no evidence as to what constitutes public interest. It can, therefore, be argued that the matter is best left to the legislature which is better equipped to deal with these social, political and economic issues. ${ }^{9}$ Lastly, where contracting parties have entered into a binding agreement at arm's length, such a contract should be enforceable without the possibility of interference arising as a result of the vagaries of the doctrine of public interest. ${ }^{10}$

The reluctance of the courts to become involved with the public interest concept is supported by the lack of case law on the topic. One of the few examples is Wyatt v. Kreglinger, where an employee aged sixty had been

\footnotetext{
${ }^{6}$ See supra.n.2.
}

${ }^{7}$ For a discussion as to whether the present legal rules on restrictive covenants in contracts of employment are economically efficient see Michael J. Trebilcock, The Common Law of Restraint of Trade: a Legal and Economic Analysis, (Sweet \& Maxwell, London, 1986), at 142.

${ }^{8}$ See Richardson v. Mellish [1824], 2 Bing. 229 at 252 per Burroughs J. - "Public policy is a very unuly horse, and once you get astride it you never know where it will carry you. It may lead you from the sound law. It is never argued at all but when other points fail."

"See Richardson v Mellish ibid. at 242 per Best C.J.- "Let that doubtful question of policy be settled by that high tribunal namely, the legislature, which has the means of bringing before it all the considerations that bear on the question."

${ }^{10}$ For further discussion of the problems of public interest see J.D. Heydon, The Restraint of Trade Doctrine, (Butterworths, London, 1971) at $270 \mathrm{ff}$. 


\section{DENNING LAW JOURNAL}

promised a pension by his employer provided he did not take up a competing trade on his leaving. ${ }^{11}$ In an unusual reversal of roles the employee sued for his pension and the employer claimed the restraint was unreasonable. The court held the covenant to be unreasonable as it would deprive the country of the services of a sixty year old man who was competent to work. With early retirement and ageism now so prevalent it is doubtful whether the court would reach the same conclusion today.

It is, therefore, "the interest of the parties" that has drawn the attention of the courts and given rise to the recent case law; particularly in regard to the employer having a "proprietary interest" to protect. ${ }^{12}$ As an employee is an agent of the employer, there is no need for a covenant not to compete with the employer, or disclose confidential information during (as opposed to after) the period of employment as this will be implied ${ }^{13}$ although it is usual for an appropriate clause to be inserted in a service agreement. However, trade secrets and employer know-how (as opposed to employee know-how and special skills) are proprietary interests which require protection after employment has ceased. ${ }^{14}$ The courts have resorted to both "philosophical" 15 and "psychological" tests. ${ }^{16}$

${ }^{11}$ [1933] 1 K.B. 793 (C.A.). See also Thomas Cowan \& Co. v. Orme [1960] 27 M.L.J. 41 (Singapore H.C.); Bull v. Pitney-Bowes Ltd. [1966] 3 All E.R. 384. For further discussion of public interest" see Michael J. Trebilcock, supra.n.7 at $106 \mathrm{ff}$.

${ }^{12}$ See Herbert Morris Ltd. v. Saxelby [1916] 1 A.C. 688 at 710 per Lord Parker - "the reason, and the only reason, for upholding such a restraint on the part of the employee is that the employer has some proprietary right, whether in the nature of a trade connection or in the nature of trade secrets, for the protection of which restraint is - having regard to the duties of the employee - reasonably necessary." For further discussion of "the parties interests" see Michael J. Trebilcock, supra.n.7 at 79.

${ }^{13}$ Faccenda Chicken Ltd. v. Fowler [1986] I C.R. 297. For the factors to determine whether any particular item of information falls within the implied term so as to prevent disclosure of information by an employee after his employment has ceased, see the remarks of Neill L.J. at 310 -311. For an earlier case, see Hivac Ltd. v. Park Royal Scientific Instruments Ltd. [1946] Ch. 169 (C.A.).

${ }^{14}$ See Cross J. in Printers and Finishers Ltd. v. Holloway [1964] 3 All E.R. 731 at $736 \mathrm{G}$.

${ }^{15}$ See Herbert Morris v Saxelby supra. $\mathrm{n} .12$ at 714 per Lord Shaw - "Trade secrets, the names of customers, all such things which in sound philosophical language are denominated objective knowledge - these may not be given away by a servant; they are his master's property. On the other hand, a man's aptitudes, his skill, his dexterity, his manual or mental ability - all those things which in sound philosophical language are not objective, but subjective - they may 


\section{RESTRAINT OF TRADE}

However, although guidance may be obtained from these abstract concepts, each case will have to be decided upon its own facts, which can give rise to practical uncertainties and litigation. Similar uncertainties can arise in regard to the reasonableness of a post employment restraint covenant in respect of the period of time during which it is to apply and the geographic area over which it is to operate.

\section{RESTRAINT COVENANTS DURING EMPLOYMENT}

\section{(a) Application of the Doctrine}

The initial question arises as to whether the doctrine of restraint of trade will apply to covenants arising during the course of employment. Specific authorities on this point are scant, although there are early decisions to support the proposition that the doctrine does not apply to "in employment" covenants. ${ }^{17}$ However, the position was clarified in A. Schoeder Music Publishing Co. Ltd. v. Macauley when it was confirmed that the doctrine applied to restraint covenants which operated during employment, as was the case with those taking effect after employment had ceased. ${ }^{18}$

\section{(b) "Garden Leave Agreements"}

"Garden Leave" or "Sterilisation" covenants arise when an employee terminates his employment in order to work for a competitor; or alternatively the employer terminates the contract. In such circumstances the employer will require the employee to remain uninvolved with the competitor for as long a

and they ought not to be relinquished by a servant; they are not his master's property."

${ }^{16}$ See Herbert Morris Ltd. v. Saxelby [1916] 1 A.C. 688 at 703-704 per Lord Atkinson "The respondent cannot, however, get rid of impressions left upon his mind by his experience in the appellant's works; they are part of himself."

${ }^{17}$ See Erhman v. Bartholomew [1898] 1 Ch. 671; Rely-A. Bell Burglar and Fire Alarm Co. Ltd. v. Eisler [1926] 1 Ch. 609; and Warner Bros Pictures Inc. v. Nelson [1937] 1 K.B. 209.

${ }^{18}$ [1974] 1 W.L.R. 1308. The covenant provided that the plaintiffs engaged the exclusive services of the defendant for the five year term of the service agreement. On the facts the covenant was held void. See the remarks of Lord Reid at 1314 - "Normally the doctrine of restraint of trade has no application to such restrictions (i.e. to work exclusively for an employer for a period): they require no justification. But if contractual restrictions appear to be unnecessary or to be reasonably capable of enforcement in an oppressive manner, then they must be justified before they can be enforced." 


\section{DENNING LAW JOURNAL}

period as possible. A "garden leave" provision in a service agreement will therefore, require the employee to serve out his notice during which period he will receive his salary and benefits but will not undertake his normal duties. Instead he will be required to remain at home, thus preventing him from making his talents and "know-how" available to his new employer, but allowing time for his possible successor to become established. Technically therefore, although a notice has been served on the employer by the employee (or vice versa) and the contract terminated at a future date the employee will nevertheless be working out such notice, and as such the "garden leave" provisions will take effect during the course of his employment. ${ }^{19}$

The leading case on this type of clause is Evening Standard Co. Ltd. v. Henderson, where the defendant was required to give one year's notice to terminate his employment and he was obliged not to work outside the company without the permission of his employer. ${ }^{20} \mathrm{He}$ was offered a job with a competitor whereupon he gave two months' notice of termination. The plaintiff brought an action to restrain him from working during his twelve months' notice period under the agreement and offered to pay his salary and benefits during that period, irrespective of whether he undertook his duties at work. The Court of Appeal granted the plaintiffs an injunction giving rise to "the Evening Standard Doctrine" and finding there was no serious issue as to liability. Such a clause is particularly open to abuse where there is a long period of notice under a service agreement. $^{22}$

A number of factors arise in connection with the doctrine. A court will not normally order an employee to comply with his obligations under a contract of employment and will not grant an injunction, the effect of which would amount

${ }^{19}$ See the italicised remarks of Simon Brown L.J. in J.A. Mont (U.K.) Ltd. v. Mills [1993] I.R.L.R. 172 at 176, para. 33 .

${ }^{20}$ [1987] I.C.R. 588; [1987] I.R.L.R. 64, (C.A.).

${ }^{21}$ See further Paul Goulding, supra.n.5.

${ }^{22}$ The Evening Standard decision was confirmed in Provident Financial Group p.l.c v. Hayward [1989] 3 All E.R. 298; [1989] I.R.L.R. 84 (C.A.); [1989] I.C.R. 160 although Dillon L.J. expressed caution at 165 - "The practice of long periods of "garden leave" is obviously capable of abuse. It is a weapon in the hands of the employers to ensure that an ambitious and able executive will not give notice if he is going to be unable to work at all for anyone for a long period of time." 


\section{RESTRAINT OF TRADE}

to specific performance, ${ }^{23}$ and the enforcement of such a clause would appear to be an exception to this rule. The court will not therefore, indirectly order specific performance by granting an injunction, the effect of which would be to make the defendant employee perform the contract, or be forced into "idleness and starvation." In the Evening Standard case, the plaintiffs had effectively disposed of the forced starvation argument as they had offered to pay the defendant's salary and benefits, thus there was no question of him starving. The starvation argument for not enforcing a "garden leave" clause is also further weakened as no defendant would starve during a notice period under the present welfare state, although their standard of living may be severely reduced.

A more compelling argument against indirect specific performance by way of injunction arises where the defendant had been reduced to idleness and as a result has no duties to perform and cannot, therefore, exercise his skills and talent. In such circumstances, it may be argued that the covenant is a restraint of trade and unenforceable. ${ }^{24}$ In terms of the construction and interpretation of "garden leave" agreements are the words "idleness" and "starvation" conjunctive or disjunctive? If the former, then doubts would arise as to the validity of the covenant as an employee will inevitably remain idle, and as argued above that may be considered a restraint of trade. If the latter, then as both conditions would not be required to be satisfied the employee's inevitable idleness would not prevent an injunction from being granted. ${ }^{25}$

Of more fundamental importance is whether an employer can lawfully prevent an employee from working, and conversely whether an employee has an implied right to work. If such an implied right was based on contract there would seem to be no reason why it should not be expressly excluded. If however, as a matter of public policy, each individual has a specific right to work such a clause may be void as being in restraint of trade.

These issues have not yet been fully canvassed before the courts. If, however, "garden leave" agreements are to be enforced, it does increase the bargaining

${ }^{23}$ Warren v. Mendy [1989] 1 W.L.R. 853; [1989] I.C.R. 525. This is the conclusion of a long line of cases commencing with Lumley v. Wagner [1852] 1 De G.M. \& G. 604. For statutory authority see section 236 of the Trade Union and Labour Relations (Consolidation) Act 1992.

${ }^{24}$ The point was recognised by Taylor L.J in Provident Financial Group p.l.c. v. Hayward supra.n.22 at 170 but as the notice period was only three months there was no question of the defendant's skills atrophying and the matter was left undecided.

${ }^{25}$ See per Taylor L.J. ibid.; also Paul Goulding, supra.n.5 at 106. 


\section{DENNING LAW JOURNAL}

power of an employer when confronted by a dissatisfied employee who wishes to leave and whose future career may be placed in jeopardy. These and other matters may yet render such agreements void under the doctrine of restraint of trade, particularly where the notice period is exceptionally long. ${ }^{26}$

Are damages (as opposed to an injunction) a possible or adequate remedy for an employer whose employee is in breach of a "garden leave" agreement? The court, as in the Evening Standard case, may accept that a plaintiff will suffer damage but find it impossible to decide the quantum. ${ }^{27}$ The courts have, therefore, considered the concept of damages as being an inadequate remedy and have to date assumed that it will not be a viable alternative or addition to an injunction. ${ }^{28}$ However the possibility has arisen that the courts may in future be willing to reassess the question of damages as a suitable remedy in certain circumstances. ${ }^{29}$ For example, if a stockbroker left his employer with a list of his private clients, it would be possible to ascertain the commissions received by his new employer from these "poached" clients over a specified period of time. Such a period would be defined by reference to the time limit imposed by a post employment restraint covenant. The suitability of this type of assessment would depend on the facts of each case, but does serve to illustrate that "garden leave" agreements are still in a state of evolution and subject to future scrutiny by the courts.

A further consideration is the length of notice which an employee has to serve, as the longer the notice the less chance there is of the court enforcing the agreement. ${ }^{30}$ A court may, however, impose an injunction for only part of the contractual notice period rather than the whole, where the whole period is not absolutely necessary for the protection of the employer. ${ }^{31}$ Directors' service

${ }^{26}$ For a discussion of "garden leave" agreements and a precedent of such a clause see Sean Nesbitt, "Employee Restraints: Maximising Contractual Protection" [1996] Practical Law for Companies, Vol VII, No.8, at $33 \mathrm{ff}$.

${ }^{27}$ Supra.n.20 at 594B per Lawton L.J..

${ }^{28}$ Warren v. Mendy supra.n.23 at 868 per Nourse L.J.

${ }^{29}$ Ibid; ; also Paul Goulding, supra.n. 5 at 104.

${ }^{30}$ See Provident Financial Group p.l.c. v. Hayward supra.n. 22 when there was no real prospect of serious damage to the plaintiffs from the defendant working for his new employers before the expiry of his notice period.

${ }^{31}$ GFI Group Inc. v. Eaglestone [1994] I.R.L.R. 119. 


\section{RESTRAINT OF TRADE}

agreements may be for a maximum term of five years ${ }^{32}$ or include lengthy periods of notice and the enforceability of a "garden leave" covenant in such circumstances should be carefully considered when drafting the covenant and lengthy periods of notice avoided.

In practice, however, the notice periods for both parties are usually the same. Long periods of notice tend to favour the employee as if his employment is terminated he will receive "a golden handshake" by way of compensation. A long notice period may also be acceptable to an employer who wishes to retain the services of a particularly valuable employee. Alternatively, a young ambitious employee may only require a short notice period in case an opportunity to further his career arose, and he wished to take up an alternative appointment as soon as possible. In the strict context of "garden leave" agreements, however, a relatively short period of notice is desirable in the interests of the employer to ensure the covenant is enforceable as well as reducing compensation in the event of termination. Nevertheless, an immediate conflict of interest can arise between the parties.

A "garden leave" provision can also be a relevant factor in determining the enforceability of a post employment restraint covenant. In Credit Suisse Asset Management Ltd. v. Armstrong and Others, the "garden leave" covenant applied for six months followed by a further restriction of six months after the termination of employment. ${ }^{33}$ The court held the latter covenant was enforceable as there was no basis for set off between the "garden leave" clause as against the post employment covenant. Füthermore, the court emphasised the individual's right to exercise his skills and a "garden leave" agreement, perhaps substantially in excess of a year, may accordingly render any post restraint covenant unènforceable. ${ }^{34}$

In addition for a "garden leave" agreement to be enforceable, the employer must have a proprietary interest to protect. Usually, this will mean the employee is proposing to take up employment with a direct competitor. An element of the employer's proprietary interest and goodwill is money made available to the

${ }^{32}$ See section 319 of the Companies Act 1985: periods in excess of five years have to be approved at a general meeting.

${ }^{33}$ [19,96] I.R.L.R. 450.

${ }^{34}$ Ibid. per Neill L.J. at 455, para. 44. 


\section{DENNING LAW JOURNAL}

departing employee during his former employment. ${ }^{35}$ Even, however, if an employee is paid his full salary and benefits during his notice period, a "garden leave" clause will not be enforceable if it is geographically too wide, or the period of restraint too long. ${ }^{36}$

In conclusion to avoid the various areas of uncertainty raised by the recent case law, a service agreement should contain a "garden leave" clause which (inter alia) provides that each party can give to the other a requisite period of notice to terminate the agreement; the employee must work exclusively for the employer; the employer can require the employee to cease working on termination of the agreement. In addition the employer must have a proprietary interest to protect. In the interests of the employer only the notice period must not be too lengthy so as to protect both the "garden leave" covenant and any post employment restraint covenant; and the employer should be under an obligation to pay to the employee his full pay and benefits during the "sterilisation" period; but under no obligation to provide work. ${ }^{37}$ Clauses of this type are, however, a relatively recent innovation and some of the matters referred to above may be subject to reexamination and found wanting on the grounds that they offend the interests of the parties and/or public policy and the doctrine of restraint of trade.

\section{POST EMPLOYMENT RESTRAINT COVENANTS}

\section{(a) The Distinction Between Post Employment and Post Business Restraints}

It has long been established that the doctrine of restraint of trade applies in regard to two areas of commercial activity. First, when imposed by an employer on an employee after the employment of the latter has ceased. ${ }^{38}$ Secondly, when a vendor sells his business and after completion of the sale he is subject to a

${ }^{35}$ For example Euro Brokers Ltd. v. Rabey [1995] I.R.L.R. 206, £10,000 per year entertainment expenses; GFI Group Inc. v. Eaglestone supra.n.31 at 121, para.15, $\mathfrak{E 5 9 , 6 1 6}$ entertainment expenses. para. Dff.

${ }^{36}$ See Provident Financial Group p.l.c. v. Hayward supra.n.22 per Dillon L.J. at 167

${ }^{37}$ There are other standard conditions to be included. For a precedent of a "garden leave" clause and a discussion of the topic generally see Sean Nesbitt, supra.n.26.

${ }^{38}$ Routh v. Jones [1947] 1 All E.R. 758 (C.A.); Mason v. Provident Clothing and Supply Co. Lid. [1913] A.C. 724. 


\section{RESTRAINT OF TRADE}

covenant restricting him from setting up in competition with the purchaser. ${ }^{39}$

Two questions arise. Are there different criteria as to enforceability applicable to the two sets of circumstances? Alternatively, if different criteria apply which set will be relevant in the event of an employee who is also the vendor of a business, i.e. the party concerned is acting in a dual capacity? These matters arose in Allied Dunbar (Frank Weisinger) Ltd. v. Weisinger, where a self employed salesman of financial services sold his practice to a subsidiary of Allied Dunbar, and thereafter became a consultant for a period of two years, after which he agreed not to compete with the parent company or a subsidiary of Allied Dunbar. ${ }^{40}$ The court held the covenant in the contract of sale was to be tested in accordance with the principles as between vendor and purchaser. ${ }^{41}$ Mr.J.Millet summarised the attitude of the courts to the two different types of covenant and their rationale as follows:

"It is well settled that in considering the validity of covenants in restraint of trade very different principles apply where the covenant is taken for the goodwill of a business sold by the covenantor to the covenantee. In the former case (although not in the latter) it may be legitimate to protect the covenantee from any competition by the covenantor and the courts adopt a much less stringent approach to the covenant recognising that the parties who negotiated it are the best judge of what is reasonable between them. The inclusion of such covenants may be necessary to enable the covenantee to realise a proper price for the goodwill of his business and by upholding the covenant the court may well facilitate trade rather than fetter it. ${ }^{.42}$

${ }^{39}$ Nordenfeli v. Maxim Nordenfelt Guns and Ammunition Co. supra.n.2; Herbert Morris Ltd. v. Saxelby supra.n. 12; Esso Petroleum Ltd. v. Harpers Garage (Stourport) Lid. supra.n. 1; Gledhow Autoparts Ltd. v. Delaney [1965] 1 W.L.R. 1366 per Sellers L.J. at 1372. The doctrine can also apply on cessation of self employment, e.g. on the dissolution of a partnership; or to directors of a joint venture company. As to the latter see Dawnay Day \& Co. Ltd. v. De Braconier D'Alphen [1997] I.R.L.R. 442 (C.A.).

${ }^{40}$ [1988] I.R.L.R. 60.

${ }^{41}$ Ibid. at 64, para. 21 - "... these covenants as taken for the protection of the goodwill of the business sold to the plaintiffs by the defendants, rather than for the protection of the plaintiff's present and future business as employer..."

${ }^{42}$ Ibid. at 64 para 20. See also Systems Reliability Holdings v. Smith [1990] I.R.L.R. 377 and Alliance Paper Group p.l.c. v. Prestwich [1996] I.R.L.R. 25. 


\section{DENNING LAW JOURNAL}

\section{(b) Criteria for Validity}

A clause in an employment contract restricting an employee's activities after termination of his employment is prima facie void as being in restraint of trade, unless the employer can establish that he has a proprietary interest which needs protection, and also any restraint is reasonable in the interest of both parties and the public at large. ${ }^{43}$ Accordingly, an employer cannot, therefore, prevent his former employee competing against him unless he has such a proprietary interest. ${ }^{44}$

Whether an employer's interests will be regarded as having sufficient substance to merit protection, will depend on the circumstances of each case and in particular the type of business of the employer and the role of the employee in the operation of that business. Nevertheless, it is possible to deduce that the interest which the courts will allow to be protected comes under two heads. The goodwill of the employer's business which would include trade connections with both suppliers and customers. The extent of the employer's proprietary interests in this regard will depend upon the access of the employee to such customers and connections during his employment. ${ }^{45} \mathrm{~A}$ distinction must also be made between the personality and the personal skills of the employee which engender the success of a business, and a proprietary interest which may prevent an employer from establishing a proprietary interest in regard to his customers. ${ }^{46}$

The trade secrets and information can be treated as a protectable proprietary interest if they are of a sufficiently high degree of confidentiality to warrant protection after termination of employment. In determining whether a trade secret is confidential, or is such that an employee is free to use it elsewhere, the court will take into account all the circumstances of the case; including the nature of the employment; the nature of the information itself; whether the employer impressed on the employee the confidentiality of the information and whether the relevant information can easily be isolated from other information

\footnotetext{
${ }^{43}$ Nordenfelt $\mathrm{v}$. Maxim Nordenfelt Guns and Ammunition Co. Lid. supra.n. 2.

${ }^{44}$ Attwood v. Lamont $\lceil 1920\rceil 3$ K.B. 5;

${ }^{45}$ Rex Ste wart Jeffries Parker Ginsberg Ltd v: Parker [1988] I:R.L.R. 483 (C.A.). The opportunities of a managing director to develop relationships with customers were such that a period of eighteen months was not unreasonable.
}

${ }^{46}$ See Cantor Fitzgeratd (U.K.) Ltd.'v. Wallace [1992] TIR.L.R. 215. 


\section{RESTRAINT OF TRADE}

which the employee is free to use or disclose. ${ }^{47}$

\section{(c) Types of Covenant}

(i) Non-Solicitation and Non-Dealing Covenants

The purpose of a non-solicitation covenant is to prohibit an employee from actively approaching customers of his former employer for a defined period of time after cessation of his employment with the intent that they will become customers of his new employer. ${ }^{48}$ The non-solicitation covenant is normally limited to those customers with whom the employee had contact ${ }^{49}$ during a specific period prior to the termination of his employment. ${ }^{50}$ Such a covenant will not be implied where a specific non-solicitation covenant has not been included in the contract of employment. ${ }^{51}$ The time period during which the covenant remains effective after the termination of employment must be reasonable and again will depend upon the circumstances. In practice, this will usually mean a sufficient period to allow the successor of a departing employee to establish himself with his employer's customers.

A non-solicitation covenant must be distinguished from a non-dealing covenant which prohibits a former employee from having any dealings

${ }^{47}$ Faccenda Chicken Ltd. v. Fowler supra.n. 13 at 310-311; see also Lancashire Fires Ltd. v. S.A. Lyons and Co. Ltd. [1997] I.R.L.R. 113 (C.A.) for information amounting to a trade secret which is so confidential that the employee is prevented from using it after leaving his employment, even without a restriction, it is not incumbent upon an employer to point out to an employee the precise limits which he seeks to protect as confidential.

${ }^{48}$ For the meaning of solicitation, see Cullard v. Taylor [1887] 3 T.L.R. 698, (sending letter to customers was solicitation).

${ }^{49}$ The employee must have such contact as will attract the customer's loyalty. See $S . W$. Strange Ltd. v. Mann [1965] 1 W.L.R. 629 (dealings on the telephone alone insufficient).

${ }^{50}$ Plowman v. Ash [1964] 1 W.L.R. 568. See also Dentmaster (U.K.) Ltd. v. Kent [1997] I.R.L.R. 636 (C.A.)- where a non-solicitation clause prohibiting the employee from soliciting the business of anyone who had been a customer of his employers during the last six months of his employment, and with whom he had dealt at any time during the course of his employment, was enforced. The subsequent restraint period was also for six months. In particular, see the remarks of Waite L.J. at 638, para. 17- "For my part given the brevity of the restraint period and the limitation of this restraint to customers within the previous six months, I find nothing illogical in the absence of a backward temporal limit on the employees dealing with such customers."

${ }^{51}$ Wallace Bogan \& Co. v Cove [1997] I.R.L.R. 453. 


\section{DENNING LAW JOURNAL}

whatsoever with the customers of his former employer. Unlike a non-solicitation covenant, a non-dealing covenant is passive in nature and does not require an active approach to former employer's customers, i.e. a customer could himself approach the former employee. The latter covenant is, therefore, wider in nature than a non-solicitation clause, as it involves interference with the rights of third parties to enter into contracts. Evidentially, there is no need for the plaintiff to prove that an approach to a customer has been made by the former employee. As a result, the courts have approached such covenants with circumspection, and the plaintiff will have to establish that, as with a non-solicitation covenant, he has valid interests to protect, and there was a personal connection between the former employee and his customers. Nevertheless, the courts will enforce such covenants even if a customer makes it clear that he no longer wishes to do business with the former employer and wishes to remain a customer of the departing employee. ${ }^{52}$

\section{(ii) Former Employees}

A contract of employment may contain a covenant that a former employee will not entice away any of the employees of his former employer to work for his new employer. The employer's proprietary interest in this regard is somewhat nebulous, although generally an employer has a legitimate interest in preventing an employee from working for a new employer who is one of his competitors. ${ }^{53}$ Accordingly, the courts may be reluctant to enforce such covenants and care will be required in drafting to ensure that they are narrow in their interpretation in that they relate to the immediate colleagues of the former employee.

\section{(iii) Non-Competition}

An employer has no right to restrain an employee from competing with him after cessation of employment, and such a covenant will be prima facie void as

${ }^{52}$ John Michael Design p.l.c. v. Cooke [1987] I.C.R. 445 and the remarks of Nicholls L.J. at 449 , para $E$, - "The mere fact that a particular customer no longer wishes to remain a customer of (the former employer) but wishes in future to deal with (the ex-employee) is not per se a sound reason for excluding the customer from the scope of the injunction."

${ }^{53}$ Kores Manufacturing Co. Ltd v. Kolok [1959] Ch. 108 per Jenkins L.J. at 125. Seemingly the maintenance of a stable work force may constitute such a legitimate interest. See Dawnay Day \& Co. Lid. v. De Braconier D'Alphen supra.n.39 and in particular per Evans L.J. at 448 , para. 46 - "an employer's interest in maintaining a stable, trained workforce is one which he can properly protect within the limits of reasonableness by an undertaking of this sort. But it does not follow that that will always be the case." 


\section{RESTRAINT OF TRADE}

being in restraint of trade. ${ }^{54}$ As has been seen, to be enforceable such a covenant must be reasonable as between the parties and also in the public interest. ${ }^{55}$ Such reasonableness must be established at the time the covenant was imposed. ${ }^{56}$

Other elements also have to pass the test of reasonableness in order to establish the enforceability of a non-competition covenant. First, a restriction must not be so wide as to prevent the former employee from working elsewhere, as such a restriction could effectively amount to specific performance. ${ }^{57}$ Secondly, both the period and area of restraint must be reasonable, which will depend on the facts of each case and the individual business needs of each employer. ${ }^{58}$ All these factors pose a challenge when drafting a restraint covenant in a service agreement. The courts are not, however, unsympathetic to the dilemmas of the draughtsman facing this task. ${ }^{59}$

The courts are nevertheless, somewhat ambivalent towards the construction of restraint covenants; alternating between a strict construction of them against the covenantee, or attempting to bring them within the scope of reasonableness and avoid declaring them void, although the recent approach has been to adopt the

\section{${ }^{54}$ Routh v. Jones supra.n. 38.}

${ }^{55}$ Nordenfelt $\mathrm{v}$. Maxim Nordenfelt Guns and Ammunition Co. Ltd. supra.n.2; also per Lord Macnaghten at 565- "It is sufficient justification, and indeed it is the only justification, if the restriction is reasonable - reasonable that is, in reference to the interests of the parties concerned and reasonable in reference to the interests of the public." In that case the protective words were unusual in that they were worldwide. Cf. Littlewoods Organisation Ltd. v. Harris [1977] 1 W.L.R. 1472 when a worldwide restraint was limited to the U.K..

${ }^{56}$ Home Counties Dairies Ltd. v. Skilton [1970] 1 W.L.R. 526; Business Seating (Renovations) Ltd. v. Broad [1989] I.C.R. 729.

\section{${ }^{57}$ Whitwood Chemical Co. v. Hardman supra.n.5.}

${ }^{58}$ For example Stenhouse Australia Ltd. v. Philips [1974] A.C. 391- five year restriction on the managing director of an insurance broking company upheld. Dowden \& Pook Ltd. v. Pook [1904] 1 K.B. 45- on the facts a restriction without any geographical limit in area held invalid. See also Mason v. Provident Clothing and Supply Co. Ltd. supra. n. 38.

${ }^{59}$ See Home Counties Dairies Ltd. v. Skilton [1970] 1 W.L.R. 526 at 538 per Cross L.J."It is in practice extremely difficult to frame restrictions which will adequately protect a trade connection and may not at the same time cover some cases where a breach will not injure the trade connection. If the court can see that the restriction has been carefully framed for a legitimate purpose, I do not think it should hold it void as contrary to public policy in favour of an employee who is in flagrant breach of it on such narrow grounds as those relied on in this case." 


\section{DENNING LAW JOURNAL}

latter of the two alternatives..$^{60}$

\section{(d) Anticipatory and Post Termination Breach of Fiduciary Duties}

The general duty of good faith which an employee owes to his employer places a restriction on working, either during working hours, or in his spare time, for a competitor or in competition with the interests of his employer. ${ }^{61}$ Such a duty is particularly explicit in the case of company directors who are in a fiduciary relationship to their companies. ${ }^{62}$ Furthermore, a director will be required to account for any profit he has made from a transaction carried out in breach of such a duty. ${ }^{63}$ The duty can also apply both during and after employment. ${ }^{64}$

The breach of the implied duty of good faith or an express provision in a service agreement also extends to action taken by an employee during the continuance of his employment in anticipation of the employment being terminated, when such actions can, or are likely to, damage the interests of the employer. The law was succinctly summarised by Lord Justice Greer in Wessex Dairies Ltd. v. Smith:

"[The employee] is under the ordinary implied obligation... namely that during the continuance of his employment he will act in his employer's interests and not use the time for which he is paid by the employer for furthering his own interests. $" 65$

${ }^{60}$ See J.D Heydon, supra.n.10 at 122-136; and P.L. Davies, "Post Employment Restraints: Some Recent Developments" [1992] J.B.L. 490 at 501.

${ }^{61}$ Hivac Ltd. v. Park Royal Scientific Instruments Ltd. supra.n. 13. The decision reversed a trend whereby a director would not be restrained from working for a competing company. See London and Mashonaland Exploration Co. [1891] W.N. 165 approved by Lord Blanesborough Bell v. Lever Bros. [1932] A.C. 161 at 195 (H.L.). For a detailed submission that the former case was wrongly decided see Michael Christie, "The Director's Duty not to Compete" [1992] 55 M.L.R 506.

${ }^{62}$ Cook v. Deeks [1916] 1 A.C. 554; 85 L.J.P.C. 161 (P.C.).

${ }^{63}$ Industrial Developments Ltd. v. Cooley [1972] 1 W.L.R. 443.

${ }^{64}$ Thomas Marshall v. Guinle [1978] 3 W.L.R. 116; [1978] I.C.R. 905.

${ }^{65}$ [1935] 2 K.B. 80 at 84 . The defendant personally approached his employer's customers to resort to his business once he had set it up after his employment had terminated. See also Robb v. Green [1895] 2 Q.B. 315- copying the names and addresses of his employer's customers with 


\section{RESTRAINT OF TRADE}

There is also an implied duty of confidentiality which is not limited solely to the relationship of employer and employee. Equity will, therefore, protect a person from conveying confidential information to a third party. ${ }^{66}$

It is also prudent to include a specific clause in a service agreement dealing with confidentiality, so that the relevant issues are clearly defined and there can be no misunderstandings. Employers may, however, consider such a clause to be of such importance as to merit a separate "Trust and Confidence Agreement" defining the information protected in full detail, e.g. inventions, patents, copyrights, etc., and the obligations placed on the employer after termination of his employment. ${ }^{67}$

A director of a company is also under a duty not to make a secret profit from his utilisation of the assets of the company and opportunities and information available to him arising from his role as a director. ${ }^{68}$ Such a duty arises irrespective of the terms of any service agreement, either in regard to a specific duty or post termination restraint of trade. A director, who specifically resigns (falsely alleging ill health) to exploit a commercial opportunity known to him in his capacity as director, will be in breach of duty, even though his former employer would not have in any event received the benefit of the transaction in question. Also, the director will be liable to account for any secret profit. ${ }^{69}$ Further the duty does not end when a director's employment is terminated and he is, therefore, prevented from pursuing maturing business opportunities which he

a view to use by the employee on setting up his own competing business. Confirmed in Roger Bullivant Ltd. v. Ellis [1987] I.C.R. 464. It may be difficult to prove where a list of names has been committed to memory, Hart v. Colley [1890] 59 L.J. Ch. 355. See also Pennycuick V-C in Baker v. Gibbons [1972] 2 All E.R. 759 at 765.

${ }^{66}$ Segar v. Copydex Lid. [1967] 1 W.L.R. 923 at 931, para E per Lord Denning- "The law on this subject depends... on the broad principle of equity that he who has received information in confidence shall not take advantage of it."

${ }^{67}$ See Practical Commercial Precedents [1986] (Rel. 27) (gen.ed. Jeffrey Green), Volume 1, Part E, Employment Precedent E. 4.

${ }^{68}$ Boston Deep Sea Fishing Co. Ltd. v. Ansell [1888] 39 Ch. D. 339. The duty can also arise in respect of a senior employee- Canadian Aeroservices Lid. v. O'Malley [1973] 40 D.C.R. (3d) 371 .

${ }^{69}$ Industrial Development Consultants Lid. v. Cooley supra.n.63 where the service agreement of a managing director contained no express covenants. See also Thomas Marshall (Exports) Ltd. v. Guinle supra.n.64; Cranleigh Precision Engineering Ltd. v. Bryant [1964] 3 All E.R. 289. 


\section{DENNING LAW JOURNAL}

was engaged upon for his employer prior to his leaving, where the resignation was prompted by a desire to acquire the opportunity for himself. ${ }^{70}$

\section{WRONGFUL TERMINATION}

If an employee who is subject to a restraint covenant on termination of his employment is wrongfully dismissed, then such covenant is void and unenforceable. This general principle was enunciated in General Bill Posting Co Ltd. v. Atkinson, when the employers agreed with their manager that his employment could be terminated on twelve months' notice by either party, with a restriction on his right to trade after its termination. ${ }^{71}$ The employers having wrongfully dismissed him without notice, it was held he was entitled to treat the dismissal as a repudiation of the contract, to sue them for damages, and that he was no longer bound by the restraint covenant. In practice, however, a contract of employment usually includes a clause that a restraint covenant will take effect on the termination of employment, for example "for whatsoever reason" or "howsoever determined." Such clauses, or clauses with similar wording, have however, been upheld by the courts over a number of years. ${ }^{72}$

However, the validity of these types of covenant was attacked in the recent case of $D$ v. $M$, where restrictions on the defendant's former managing director's activities were to apply after his employment was "terminated for any reason whatsoever" and "irrespective of the cause or manner" were held to be

${ }^{70}$ Island Export Finance Lid. v. Umunna [1986] B.C.L.C. 460 where on the facts the plaintiff's claim failed as the defendant's resignation was not prompted by the desire to take advantage of a maturing opportunity.

${ }^{71}$ [1909] A.C. 118. See further at 121 per Lord Robertson - "It seems to me that the covenant not to set up business is not only germane to but ancillary to the contract of service, and that once the contract of service is rescinded the other falls with it."

${ }^{72}$ Dairy Crest Ltd. v. Piggott [1989] I.C.R. 92- "after the termination or cessation in any manner;" Business Seating (Renovations) Ltd. v. Broad supra.n.56- "for any cause whatsoever" and "howsoever effected;" Lansing Linde v. Kerr [1991] 1 All E.R. 418- "howsoever caused." See also Rock Refrigeration Ltd. v. Jones and Seward Refrigeration Ltd. [1996] I.R.L.R. 675 at 679, para. 38 per Morritt L.J.- "No fewer than 12 reported cases decided between 1964 and 1991 in which covenants in similar terms were not alleged or found to be invalid on this ground." 


\section{RESTRAINT OF TRADE}

unreasonable on their face and unenforceable. ${ }^{73}$ Accordingly, there was no issue to be tried. The clause was determined unenforceable as its purpose was to secure coercive rights to the employer, which would survive his own contractual misconduct. The decision, that covenants of this type were unenforceable, has serious practical consequences as they are extant in many existing contracts of employment.

This difficulty has now been resolved, as the Court of Appeal in the recent case of Rock Refrigeration Lid. v. Jones and Another where the defendant had given lawful notice under his contract of employment and joined a competitor, held accordingly that there was no question of wrongful termination. ${ }^{74}$ The issue in question was whether a restriction covenant, which is expressly provided to take effect upon the termination of a contract of employment "howsoever occasioned" was necessarily unreasonable and thus unenforceable. The court held in revising $D$ v. $M$ that where there is a repudiatory breach of the contract of employment by the employer the principle in General Bill Posting Co.Ltd. v. Atkinson applies; the employee is released from his obligations under the contract and restrictive covenants against him cannot be enforced. The court further held that a covenant, otherwise reasonable, that purported to remain binding in circumstances where it was impossible to enforce it could not, on that account, be in unlawful restraint of trade; and that therefore, the restrictive covenants in the first defendant's contract were enforceable unless/until the plaintiff committed a repudiatory breach.

The effect, therefore, of the decision is that a restraint covenant will not be unenforceable merely because it is drafted to take effect after termination of the contract of employment, for example, "howsoever occasioned" or in other similar terms. The restraint clause will in such circumstances stand or fall in accordance with the restraint of trade doctrine. Nevertheless, where there is a repudiatory breach of contract by the employer the employee will be released from the contract and the restraint covenant in accordance with the principle of General Bill Posting Co.Ltd. v. Atkinson.

${ }^{73}$ [1996] I.R.L.R. 192. See also Living Design (Home Improvements) Ltd. v. Davidson [1994] I.R.L.R. 69; PR Consultants Scotland Ltd. v. Mann [1996] I.R.L.R. 188; Briggs v. Oates [1990] I.R.L.R. 472.

${ }^{74}$ [1996] I.R.L.R. 675; [1997] I.C.R.938. For drafting considerations arising as a result of the decision see Steve Wilson \& Mick Woodley, "Terminating a Restraint Clause" (1997) 141 S.J.14; also Michael Jefferson, "Restraint of Trade: Dismissal and Drafting" [1997] 26 I.L.J.62. For a consideration of the theory on the law of discharge see P.L. Davies, supra.n.60 at 494. 


\section{DENNING LAW JOURNAL}

\section{SEVERANCE}

Where a restraint covenant contains in part an enforceable restriction, and also in part a restriction which is unenforceable, the courts may strike out the latter and thereby sever the one from the other. Unsurprisingly, the courts view such a procedure with caution; ${ }^{75}$ nor will the court rewrite the covenant. ${ }^{76}$

Two tests as to the application of the doctrine have emerged from the case law. First, the part of a covenant which is severed must be separate and distinct from the other, and the underlying meaning of the clause must remain. ${ }^{77}$ Secondly, the "blue pencil" test where the words severed must constitute a generally separate covenant, and do not form an integral part of a single covenant, and can be severed without affecting the meaning of the remaining part. ${ }^{78}$ Put simply, this means the offending words can be literally deleted without affecting the remaining words as they were actually written. The remaining enforceable terms must also be supported by adequate consideration. ${ }^{79}$

Clearly in drafting restraint covenants they should be kept separate and independently defined so as to make severance more easily applicable if such an eventuality should arise.

\section{DRAFTING CONSIDERATIONS}

The difficulties facing the draughtsman of a restraint covenant, whether acting for an employer or an employee, were succinctly summarised by Lord Justice Pearson in Commercial Plastics v. Vincent:

${ }^{75}$ Mason v. Provident Clothing and Supply Co. supra.n.38 at 745 per Lord Moulton"But... that ought only to be done in cases where the part so enforceable is clearly severable, and even so only in cases where the excess is of trivial importance, or merely technical, and not part of the main purport and substance of the clause."

${ }^{76}$ Ibid. at 745 per Lord Moulton.

${ }^{77}$ T. Lucas \& Co Lid. v. Mitchell [1972] 1 W.L.R. 938.

${ }^{78}$ Attwood v. Lamont supra.n.44.

${ }^{79}$ Marshall v. N.M. Financial Management Ltd. [1997] I.R.L.R. 449 (C.A.) where an entitlement to the payment of post termination commission was held severable and payable. The consideration for the payment of the renewal commission being the employee's services in procuring business before his resignation. 


\section{RESTRAINT OF TRADE}

"It would seem that a good deal of legal "know-how" is required for the successful drafting of a restraint covenant.,

Given the present and future uncertainties in respect of these covenants, the busy practitioner has to give careful consideration as to how, if possible, any pitfalls can be avoided. Although it is difficult to predict the future view a court may adopt, various clauses can be included in contracts of employment which may offer limited protection for the interests of the parties.

One such device is a "savings" clause discussed by the Court of Session in Hinton \& Higgs (U.K.) Ltd. v. Murphy and Valentine, where the clause contemplated that the parties would abide by a result which could be effected by the deletion of some unreasonable part of the contract rendering the contract as a whole reasonable. ${ }^{81}$ Since that did not involve rewriting the contract (which the court would not undertake) but selecting that version which the parties (inter alia) had made with each other, and thus enabling the modified bargain to stand, there was no reason why the court would refuse to perform that role. On the facts, however, the clause was held unreasonable as being too wide in its geographical limitation. Such a clause is of limited value as the draughtsman is attempting to second guess the reaction of the court, and in any event, a resulting modification may only be of a relatively minor nature as the contract cannot be rewritten.

A less specific arrangement would be for the parties to agree that the part of the clause held void is deemed not to form part of the contract, but the remaining part shall be valid. Such a clause, in effect, merely anticipates severance by the court. When acting for an employer there would, therefore, seem to be little alternative but to err on the side of caution and draft a restraint covenant that is strictly limited in scope so as to ensure enforceability.

When acting for the prospective employee the balance of negotiating power may, more often than not, rest with a large wealthy employer. The risks undertaken by the employee will be greater as he or she may leave a relatively secure appointment, move house, home and family, when taking up a new post and entering a restraint covenant. Also on termination of employment a covenant may be unenforceable, but the employee will not be able to meet the expense and

${ }^{80}[1965] 1$ Q.B. 623 at 647.

${ }^{81}$ [1989] I.R.L.R. 519. The contract provided that " $\ldots$ in the event that any such restriction shall be void would be valid if some part thereof were deleted... such restrictions shall apply with such modifications as may be necessary to make them valid or effective." 


\section{DENNING LAW JOURNAL}

risk of litigation. A compromise solution would be for the restraint covenant only to take effect after an agreed period from the commencement of employment say, for example, one year. This would give an employee an opportunity to assess his new appointment during the first year, and if dissatisfied leave without fear of being manacled by a restraint covenant. Conversely, a covenant of this type may not be acceptable to an employer, who will require a full and immediate commitment from the new recruit; tactful negotiation would, therefore, be required on the part of the prospective employee.

\section{CONCLUSION}

The courts have a long history of decisions in regard to covenants in restraint of trade in regard to contracts of employment going back to the latter part of the last century, and the unwary may be tempted to assumed all the relevant issues have been resolved. Such an assumption would, however, be unfounded. Generally it has always been difficult to balance the interests of the employer and employee, whilst also taking into account the public interest in deciding the enforceability of restraint covenants. In addition, constant change in commercial and business activities linked with the increase in the importance of "know-how" and technology have raised further questions which have had to be resolved. Hence the recent spate of cases in the courts. ${ }^{82}$ It would also be imprudent to conclude that the courts will remain inactive in this area as "garden leave" agreements are, for example, still in a state of evolution. All these factors give rise to problems in respect of both the drafting and interpretation of these covenants. Care and a perspicacious outlook in regard to future developments are therefore required.

${ }^{82}$ For a further consideration of some recent cases see Charles Wynn-Evans, "Restrictive Covenants and Confidential Information - Some Recent Cases" [1997] 18 Bus.Law.Rev. 247. 